\title{
Profissionalismo Docente
}

Recebido em 15.12.2015. Aprovado em 20.01.2016 Avaliado pelo sistema double blind review

\author{
Maria Cristina Machado Grosso \\ ce237@sesisp.org.br \\ Centro Educacional SESI 237 - Guararapes - SP - Brasil
}

\section{Resumo}

Estudos têm revelado que as dificuldades crescentes com as quais se defrontam os professores no exercício de suas funções são reflexos diretamente ligados á crise de identidade e de poder dos docentes. 0 entendimento sobre o que significa ser professor, tanto no quadro legal e curricular, como nos modos de ser e de estar na profissão, assenta em diferentes perspectivas de encarar o papel dos docentes no desenvolvimento do currículo, e nas suas funções no contexto da escola e do sistema educativo. A identidade profissional do professor está relacionada com a imagem que tem de si próprio e com a importância que a sociedade atribui ao seu trabalho, o que depende de diferentes fatores: da forma que se relaciona com os seus alunos, da área de conhecimento que atua, dos diferentes papéis que desempenha, das condições de trabalho, da sua história de vida, da formação inicial e também em serviço, e de outros aspectos ligados diretamente ao ambiente escolar.

É escopo deste Plano de Empreendimento resgatar e reconstruir a profissionalidade docente que se apresenta fragilizada, refletindo diretamente nos resultados de aprendizagem dos estudantes, especialmente a partir do Ensino Fundamental II, considerando que uma das bases históricas fundamentais para que 0 professor consiga o reconhecimento de sua autoridade é a posse do conhecimento.

Nessa perspectiva pretende-se desenvolver entre os docentes a compreensão de que a escola é um campo de aprendizagem em todas as dimensões, ou seja, não só para o estudante, mas para o professor também, onde a atuação competente de cada profissional é valorizada com espaços dignos destinados ao compartilhamento de saberes e experiências exitosas entre seus pares.

Espera-se que ao fortalecer o papel deste profissional estaremos contribuindo para que ele assuma habilidades mais complexas e variadas, quais sejam: competências profissionais, que não se referem apenas à detenção do saber, mas à mediação entre o saber e o estudante; uma cultura profissional, que se refere ao estabelecimento de relações entre o processo educativo, a escola e a cultura; e uma identidade profissional, que se refere à identificação com o grupo a que pertence.

Desta forma no desenvolvimento do projeto os professores seguros do seu protagonismo, juntamente com outros membros da comunidade escolar serão mobilizados e estimulados a construir um Plano de Melhoria que impacte positivamente na aprendizagem dos estudantes e nos resultados da escola.

Palavras-chaves: Plano de Empreendimento. Empreendedorismo e Educação. Formação Docente. 


\section{Caracterização da Escola}

O Centro Educacional SESI 237, localizado em Gurararapes (SP), atende a 339 alunos do Ensino Regular e 103 alunos da Educação de Jovens e Adultos. As séries atendidas são: Educação Básica - Ensino Regular: Ensino Fundamental I (10 ao 50 ano), Ensino Fundamental II (6o ao 90 ano) e Ensino Médio (10 ao 30 ano); Educação de Jovens e Adultos - Educação a Distância - Ensino Fundamental e Ensino Médio.

A escola tem como missão "Oferecer a formação integral do aluno em vários aspectos de sua vida social, cognitivo, psicológico e afetivo - por meio de uma educação que contemple de forma articulada esses aspectos e o prepare para o exercício de sua cidadania de forma autônoma", e a visão de "Ser referência na qualidade da formação integral do aluno em todas as modalidades de ensino".

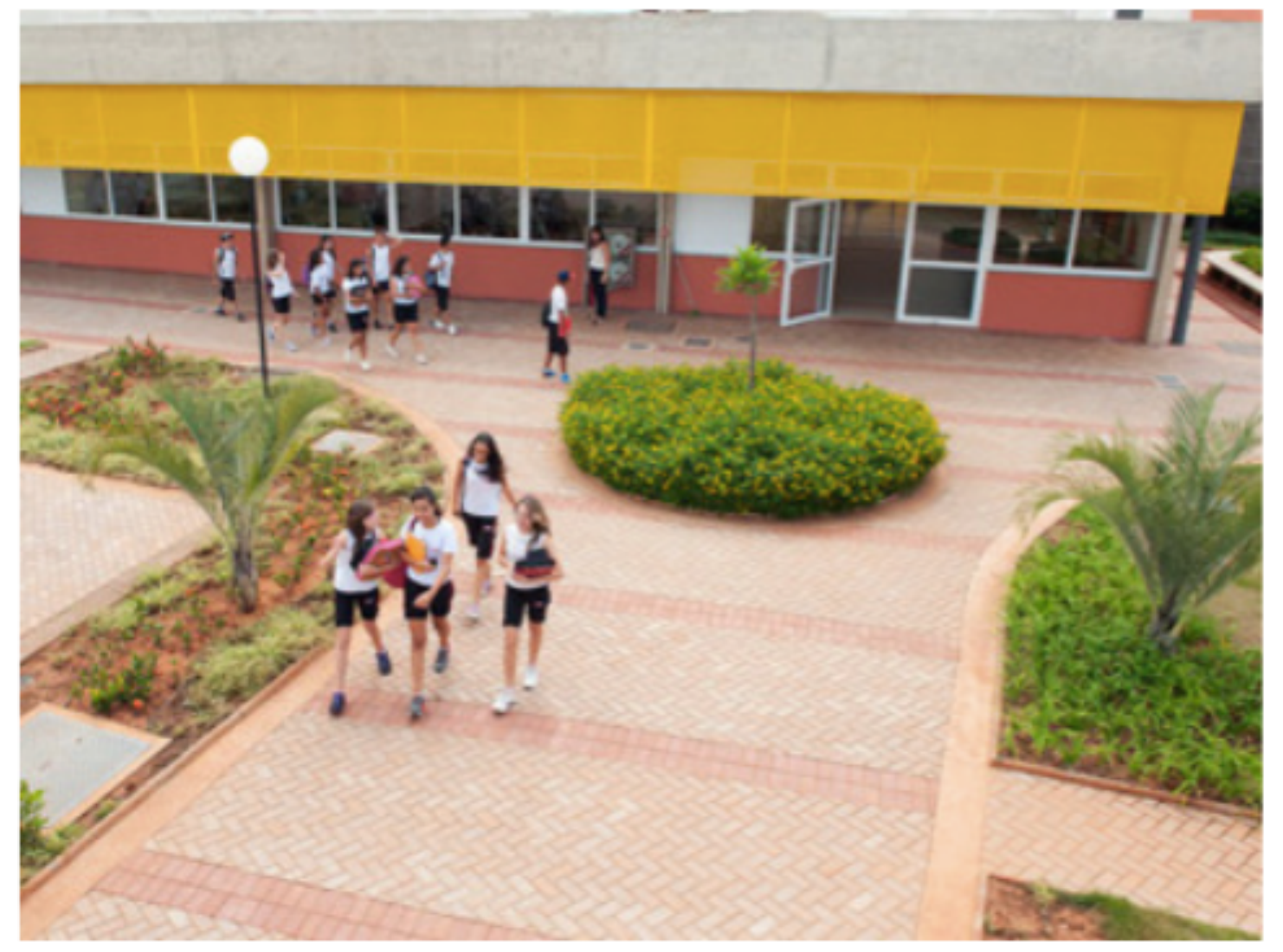

\section{Instalações}

O Centro Educacional SESI 237- Guararapes está instalado num prédio novo desde quinze de março de dois mil e treze, com 23 mil metros quadrados, ampla área verde de excelente construção, áreas livres e locais para estacionamento de veículos e bicicletas. 0 espaço é composto por 02 blocos, portaria, caixa d'água e reutilização de água, lixeira, abriga para gás e quadro de energia.

No bloco temos a área de circulação, sanitários para alunos e NEE, 01 copa para funcionários, 01 sala de professores, 01 sala de coordenadores pedagógicos, 11 salas de aula, 01 laboratório de ciências Físicas, 01 laboratório de Ciências Químicas e Biológicas, área de convivência com mesas e cadeiras, sanitário de professores.

No bloco 2 temos o saguão, laboratório de informática educacional, cozinha, 01 sala de aula, 01 laboratório de ciências e tecnologia, refeitório, almoxarifado, sala de atendimento a pais, biblioteca escolar, sanitário de funcionários, alunos e NEE, área de convivência.

As salas de aula são amplas, assim como os corredores e a escadaria de acesso ao piso superior da quadra poliesportiva. Na parte externa, tem-se amplo espaço aberto no qual contamos com um playground. 
A conservação, em geral, é boa, a limpeza é realizada diariamente pelos auxiliares de serviços gerais de empresa terceirizada, bem como os serviços de jardinagem, portaria e vigilância. Os ambientes descritos têm auxiliado o público interno a desenvolver suas atividades com mais qualidade.

A Escola está equipada com diversos materiais pedagógicos não especificados nesse plano, porém relacionados em uma listagem que fica à disposição de toda comunidade escolar.

A escola oferece serviço de alimentação saudável visando a reeducação alimentar que contribuindo para a formação de hábitos alimentares saudáveis Todos os alunos com restrições alimentares (diabetes, obesidade, alergias intolerância alimentares, entre outras) recebem dieta especial, desde tragam a prescrição médica e/ou do nutricionista da Unidade Escolar.

\section{Breve histórico}

\begin{tabular}{|c|c|}
\hline Ano & \begin{tabular}{c} 
Acontecimentos relevantes \\
\hline 1965
\end{tabular} \\
\hline 1995 & Fundação da escola, no bairro Centro \\
\hline 2010 & $\begin{array}{c}\text { Mudança de Prédio - novas instalações no bairro Jardim } \\
\text { Continental }\end{array}$ \\
\hline 2012 & Passou a oferecer Ensino Médio período integral do $1^{\circ}$ ao $6^{\circ}$ ano do Ensino Fundamental \\
\hline 2013 & Mudança de Prédio- novas instalações no bairro Jardim Satélite II \\
\hline 2013 & 15 de março - Inauguração do novo Prédio \\
\hline
\end{tabular}

\section{Professores e funcionários}

A equipe é formada por 24 professores, distribuídos da seguinte forma:

\begin{tabular}{|c|c|}
\hline Disciplina / Area & Quant. de professores \\
\hline Ensino Fundamental I & 05 \\
\hline Língua Portuguesa & 03 \\
\hline Matemática/Fisica & 03 \\
\hline Geografia & 02 \\
\hline História & 02 \\
\hline Ciências & 01 \\
\hline Arte & 01 \\
\hline Educação Fisica & 01 \\
\hline Língua Estrangeira - Inglês/Espanhol & 02 \\
\hline Biologia & 01 \\
\hline Química & 01 \\
\hline Sociologia/Filosofia & 01 \\
\hline EJA - Ensino Fundamental & 01 \\
\hline EJA - Ensino Médio & 01 \\
\hline Professoras Auxiliares Docente & 02 \\
\hline Orientação de Estudos & 01 \\
\hline
\end{tabular}

Do total de professores, 2 possuem Doutorado, 01 mestrado, 02 são pós graduados e os demais são graduados em nível superior. Com relação as experiências do corpo docente, 03 lecionam em Redes de Ensino Particulares, 02 em Universidades, 07 em Rede Estadual, 02 na Rede de Ensino Municipal e 09 são docentes apena da Rede Escolar SESI/SP.

Além disso, a escola conta com 40 funcionários de apoio, sendo 2 coordenadores pedagógicos, 01 diretor, 03 
auxiliares de serviços administrativos, 03 inspetores de alunos, 01 auxiliar de manutenção, 01 jardineiro,02 porteiros, 04 vigilantes, 06 auxiliares de serviços gerais, 05 auxiliares de cozinha, 02 nutricionistas, 01 bibliotecário, 01 analista de informática educacional, 05 estagiário, 01 professor de capoerira, 01 Supervisora Escolar, que além de supervisionar a escola, atende mais sete escolas da região, 01 Analista Técnico Educacional, que atua como formador dos Coordenadores Pedagógicos da Escola e de mais quinze escolas da região.

\section{Perfil dos alunos}

Os alunos estão distribuídos por séries e turnos da seguinte maneira:

\begin{tabular}{|c|c|c|c|c|c|c|c|c|}
\hline \multirow[b]{2}{*}{ Série/Ano } & \multirow{2}{*}{$\begin{array}{c}\text { Média } \\
\text { de } \\
\text { idade }\end{array}$} & \multirow{2}{*}{$\begin{array}{c}\begin{array}{c}\text { Total } \\
\text { de }\end{array} \\
\text { alunos } \\
\end{array}$} & \multicolumn{2}{|c|}{ Integral } & \multicolumn{2}{|c|}{ Tarde } & \multicolumn{2}{|c|}{ Noite } \\
\hline & & & $\begin{array}{l}\text { NP }^{2} \\
\text { alunos }\end{array}$ & $\begin{array}{c}\mathrm{N}^{2} \\
\text { turmas }\end{array}$ & $\begin{array}{c}\text { NP }^{2} \\
\text { alunos }\end{array}$ & $\frac{N^{2}}{\text { turmas }}$ & $\frac{N^{2}}{\text { alunos }}$ & $\frac{N^{2}}{\text { turmas }}$ \\
\hline $6^{2}$ ano & 11,5 & 34 & 34 & 1 & & & - & - \\
\hline $7^{\circ}$ ano & 12,5 & 31 & 31 & 1 & & & - & - \\
\hline $8^{2}$ ano & 13,5 & 32 & 32 & 1 & & & - & - \\
\hline $9^{2}$ ano & 14,7 & 32 & 32 & 1 & & & - & - \\
\hline $1^{2}$ E.M. & 15,9 & 29 & & & 29 & 1 & - & - \\
\hline & & & \multicolumn{2}{|c|}{ MANHA } & & & & \\
\hline $2^{2}$ E.M. & 16,8 & 31 & 31 & 1 & & & - & - \\
\hline $3^{2}$ E.M. & 18 & 47 & 47 & 2 & & & - & - \\
\hline $\begin{array}{c}\text { EJA } \\
\text { Fundamental }\end{array}$ & N/A & 44 & - & & - & - & 44 & 1 \\
\hline $\begin{array}{l}\text { EJA } \\
\text { Ensino } \\
\text { Medio }\end{array}$ & $\mathrm{N} / \mathrm{A}$ & 59 & - & - & - & - & 59 & 1 \\
\hline TOTAL & - & 339 & 207 & 07 & 29 & 1 & 103 & 2 \\
\hline
\end{tabular}

Quanto à caracterização socioeconômica e cultural da escola, a clientela constitui-se de classe social baixa e média; $70 \%$ dos alunos são filhos de pessoas que trabalham em empresas da cidade e os demais estão divididos entre: empregadas domésticas, profissionais da área da saúde, trabalhadores do comércio, comerciantes e funcionários da própria escola. Uma parte dessas famílias encontra-se desempregada. Apesar do desemprego não deixar de ter implicações nas condições de vida digna e saudável, a Escola vem se esforçando para oferecer um ensino de qualidade e confiabilidade pela atuação e competência dos profissionais que nela atuam, uma vez que as famílias esperam que a Escola contribua para a formação dos seus filhos, tanto para a vida social, como profissional.

Pequena parte dos alunos trabalha para colaborar com o orçamento familiar, em sua maioria são alunos do Ensino Médio, que fazem estágios em Empresas, Prefeitura, Fórum e comércio da cidade. A participação dos alunos nas atividades da escola é muito significativa, uma média de $95 \%$ em quase todos os eventos promovidos, considerando que todos são planejados e organizados em parceria com os mesmos. Os pais participam da vida dos filhos com maior frequência até o 60 Ano do Ensino Fundamental, a partir daí a frequência começa a diminuir e a escola começa a elaborar estratégias para incentivá-los a uma maior participação.

A maioria da comunidade tem residência própria, possuem eletrodomésticos e aparelhos de multimídia modernos. Grande parte dos alunos utiliza como meio de transporte a bicicleta para se deslocarem de sua residência à Escola, levando até 20 minutos no referido deslocamento. Uma pequena parte dos alunos utiliza o transporte coletivo oferecido pela Prefeitura Municipal, carros e vans.

Os alunos da Educação de Jovens e Adultos são todos trabalhadores que buscam uma aceleração de estudos para o sucesso pessoal e profissional. A escola procura estabelecer uma boa comunicação e relação com as famílias, o que favorece a participação nas atividades e eventos e fortalece esta importante e necessária parceria. Entretanto continuamos em processo de aprimoramento das ações para aproximar cada vez mais a família e a comunidade da escola. 


\section{Características do entorno}

A Escola está localizada em um bairro novo longe do centro, mas que indica um crescimento populacional, seus moradores são da classe média, cujas residências são novas e confortáveis. Após a inauguração da escola, no ano de 2013, constata-se um crescimento do bairro, com novas construções a cada dia. A escola contribuiu muito para a valorização e melhoria do bairro. A estrutura urbana oferece água encanada, energia elétrica em todas as casas, esgoto público, calçamento e iluminação. A maioria das famílias possui veículos e bicicletas, estas muito utilizadas pela maioria dos moradores, considerando que as ruas são planas.

Não contamos com empresas de grande porte próximas à escola, mas com pequenos comerciantes. 0 atendimento médico é precário, havendo um Pronto Socorro/hospital próximo ao centro da cidade, um Posto de Saúde próximo à Escola e os demais, em bairros mais distantes.

Perto da escola há três praças com espaço para atividade física e lazer, um clube com piscinas, lanchonete e espaço para eventos. Nessas praças a Prefeitura Municipal promove eventos em datas comemorativas importantes para a cidade. São oferecidas à comunidade projetos sociais que atendem crianças e adolescentes carentes em período contrário ao que estuda, o que contribui para um baixo índice de violência na comunidade local.

identificação do problema e da oportunidade

\section{Resultados SARESP dos últimos três anos}

\section{Língua portuguesa}

\begin{tabular}{|c|c|c|c|}
\hline $\begin{array}{l}\text { MÉDIA } \\
\text { SESI }\end{array}$ & LÍNG & $\begin{array}{r}\text { CE23 } \\
\text { UA POR } \\
3^{\circ} \text { ano }\end{array}$ & $\begin{array}{l}\text { JGUESA } \\
\text { :F }\end{array}$ \\
\hline \multirow{2}{*}{228,6} & 2012 & 2013 & 2014 \\
\hline & $100 \%$ & $96,70 \%$ & 252,6 \\
\hline \multirow{3}{*}{ 239,3 } & \multicolumn{3}{|c|}{$5^{\circ}$ ano EF } \\
\hline & 2012 & 2013 & 2014 \\
\hline & 237,8 & & 239,8 \\
\hline \multirow{3}{*}{262,3} & \multicolumn{3}{|c|}{$7^{\circ}$ ano EF } \\
\hline & 2012 & 2013 & 2014 \\
\hline & 253,7 & 249,3 & 257,8 \\
\hline \multirow{3}{*}{275,5} & \multicolumn{3}{|c|}{$9^{\circ}$ ano } \\
\hline & 2012 & 2013 & 2014 \\
\hline & 266,7 & 271,9 & 263,5 \\
\hline \multirow{3}{*}{312,7} & \multicolumn{3}{|c|}{$3^{\circ}$ ano EM } \\
\hline & 2012 & 2013 & 2014 \\
\hline & 314,7 & 310,4 & 311,1 \\
\hline 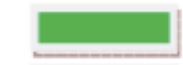 & \multicolumn{3}{|c|}{ Arima da márlia CFSI } \\
\hline ב & \multicolumn{3}{|c|}{\begin{tabular}{|l|l|l} 
Na mádia CFCI p om nularla \\
\end{tabular}} \\
\hline$\square$ & \multicolumn{3}{|c|}{\begin{tabular}{|l|l|} 
Abaixo da Médlia e em avnco \\
\end{tabular}} \\
\hline & \multicolumn{3}{|c|}{\begin{tabular}{|l|l} 
Abaixo da média SESI e em aueda \\
\end{tabular}} \\
\hline
\end{tabular}

\section{Matemática}




\begin{tabular}{|c|c|c|c|}
\hline $\begin{array}{c}\text { MÉDIA } \\
\text { SESI }\end{array}$ & LÍNG & $\begin{array}{r}\text { CE23 } \\
\text { UA POR } \\
3^{\circ} \text { ano }\end{array}$ & $\begin{array}{l}\text { UGUESA } \\
\text { F }\end{array}$ \\
\hline & 2012 & 2013 & 2014 \\
\hline 242,3 & $100 \%$ & $96,70 \%$ & 274,3 \\
\hline & & $5^{\circ}$ ano & $F$ \\
\hline ?52 & 2012 & 2013 & 2014 \\
\hline 203,2 & 237,8 & 246,4 & 253,3 \\
\hline & & $7^{\circ}$ ano & $F$ \\
\hline 2753 & 2012 & 2013 & 2014 \\
\hline 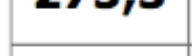 & 253,7 & 249,3 & 267,6 \\
\hline & & $9^{\circ}$ an & \\
\hline 297,6 & 2012 & 2013 & 2014 \\
\hline & 266,7 & 271,9 & 292,4 \\
\hline & & $3^{\circ}$ ano & $M$ \\
\hline 323,3 & 2012 & 2013 & 2014 \\
\hline & 314,7 & 310,4 & 311,3 \\
\hline & $\Delta$ rima da més. & Sdia SFSI & \\
\hline$n$ & Na móndia SFC & SI e avanen & \\
\hline 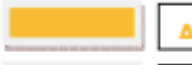 & $\Delta$ Ahairen da Ma & ónlia a am aun & \\
\hline$\square$ & Abaixo dz & aSESI & \\
\hline
\end{tabular}

Ao analisarmos o histórico dos resultados SARESP da escola, nos últimos três anos observamos que até nos anos iniciais, do 10 ao 50 ano os resultados de aprendizagem dos alunos vem avançando, ficando na média dos demais alunos da rede SESI. Entretanto um movimento de queda do desempenho dos alunos, tanto em Língua Portuguesa, quanto em Matemática, se inicia nos anos finais do Ensino Fundamental, a partir do 70 ano, aumentando, progressivamente até 030 ano do Ensino Médio. Esses dados nos apontam para uma investigação e análise minuciosa da trajetória dos alunos nas avaliações internas, como também para um levantamento de diferentes indicadores que interferem diretamente na aprendizagem dos alunos, como:

- Principais dificuldades observadas no desempenho dos alunos;

- Se as dificuldades apresentadas são identificadas nas avaliações internas;

- Se os alunos com nível de proficiência abaixo do básico, são os mesmos que apresentam baixos resultados nas avaliações internas;

- Se há ações específicas voltadas para as dificuldades elencadas;

- Se há estratégias para monitoramento das ações propostas;

- Se há análise criteriosa das atividades que os docentes desenvolvem, visando superar as dificuldades;

- Se há ações específicas com os alunos que estão abaixo do nível adequado;

- Índice de absenteísmo docente;

- $\quad$ Nível de exigência nas avaliações internas; Considerando esses itens de análise constata-se que até o 50 ano existe muita coerência no processo avaliativo, uma vez que os alunos que estão no nível de proficiência abaixo do básico na avaliação externa, são os mesmos que os professores apontam como alunos 
com dificuldade, para os quais planejam atividades diferenciadas, voltadas para suas reais dificuldades. Constatamos ainda que o índice de absenteísmo docente do 10 ao 50 ano ( $2 \%$ ano) é muito abaixo do índice dos professores do 60 ao 90 e Ensino Médio (13\% ano), o que também interfere nos resultados de aprendizagem dos alunos. Quanto ao nível de exigência nas avaliações, constata-se que os professores do 60 ao 9o, apesar de declararem verbalmente as dificuldades encontradas no dia a dia em sala de aula, devido ao desinteresse e descompromisso dos alunos, no final da etapa atribuem conceitos satisfatórios a todos os alunos, o que é validado na tabela a seguir com o número de aprovados, $100 \%$ do 60 ano do Ensino Fundamental, ao 30 ano do Ensino Médio. Entretanto o índice de alunos aprovados pelo Conselho de Classe, nesses anos é de 30\%. Os professores sempre acabam decidindo pela aprovação, considerando que não possuem registros e atividades que evidenciem um trabalho diferenciado com os alunos que apresentam dificuldades, o que contraria a concepção de ensino e aprendizagem da rede SESI-SP, que pressupõe ação mediadora do docente e vivência da avaliação formativa que possibilitem diferentes oportunidades para a aprendizagem do aluno, retomando aprendizagens ainda não consolidadas em sala de aula.

\section{NÍVEIS DE PROFICIÊNCIA DO ÚLTIMO RESULTADO SARESP/2014}

\section{Língua Portuguesa}

\begin{tabular}{|c|c|c|c|c|c|}
\hline Classificação & $\begin{array}{c}\mathbf{3}^{\circ} \\
\text { ANO } \\
\text { EF }\end{array}$ & $\begin{array}{c}\mathbf{5}^{\circ} \\
\text { ANO } \\
\text { EF }\end{array}$ & $\begin{array}{c}\mathbf{7 0}^{\circ} \\
\text { ANO } \\
\text { EF }\end{array}$ & $\begin{array}{c}\mathbf{9}^{\circ} \\
\text { ANO } \\
\text { EF }\end{array}$ & $\begin{array}{c}3^{\circ} \\
\text { ANO } \\
\text { EM }\end{array}$ \\
\hline Abaixo básico & $\mathbf{0 , 0}$ & $\mathbf{0 , 0}$ & $\mathbf{0 , 0}$ & $\mathbf{7 , 1}$ & $\mathbf{5 , 1}$ \\
\hline Básico & $\mathbf{0 , 0}$ & $\mathbf{8 , 8}$ & $\mathbf{1 7 , 9}$ & $\mathbf{5 3 , 6}$ & $\mathbf{2 5 , 6}$ \\
\hline Adequado & $\mathbf{1 1 , 8}$ & $\mathbf{6 1 , 8}$ & $\mathbf{4 6 , 4}$ & $\mathbf{3 5 , 7}$ & $\mathbf{6 6 , 7}$ \\
\hline Avançado & $\mathbf{8 8 , 2}$ & $\mathbf{3 8 , 2}$ & $\mathbf{3 5 , 7}$ & $\mathbf{3 , 6}$ & 2,6 \\
\hline
\end{tabular}

Matemática

\begin{tabular}{|c|c|c|c|c|c|}
\hline Classificação & $\begin{array}{c}\mathbf{3}^{\circ} \\
\text { ANO } \\
\text { EF }\end{array}$ & $\begin{array}{c}\mathbf{5}^{\circ} \\
\text { ANO } \\
\text { EF }\end{array}$ & $\begin{array}{c}7^{\circ} \\
\text { ANO } \\
\text { EF }\end{array}$ & $\begin{array}{c}9^{\circ} \\
\text { ANO } \\
\text { EF }\end{array}$ & $\begin{array}{c}3^{\circ} \\
\text { ANO } \\
\text { EM }\end{array}$ \\
\hline Abaixo básico & $\mathbf{0 , 0}$ & $\mathbf{0 , 0}$ & $\mathbf{3 , 6}$ & 10,7 & 15,4 \\
\hline Básico & $\mathbf{2 , 9}$ & $\mathbf{2 5 , 0}$ & $\mathbf{2 8 , 6}$ & $\mathbf{4 6 , 4}$ & $\mathbf{6 9 , 2}$ \\
\hline Adequado & $\mathbf{2 0 , 6}$ & $\mathbf{4 6 , 9}$ & $\mathbf{5 3 , 6}$ & $\mathbf{3 2 , 1}$ & $\mathbf{1 2 , 8}$ \\
\hline Avançado & $\mathbf{7 6 , 5}$ & $\mathbf{2 8 , 1}$ & 14,3 & 10,7 & 2,6 \\
\hline
\end{tabular}

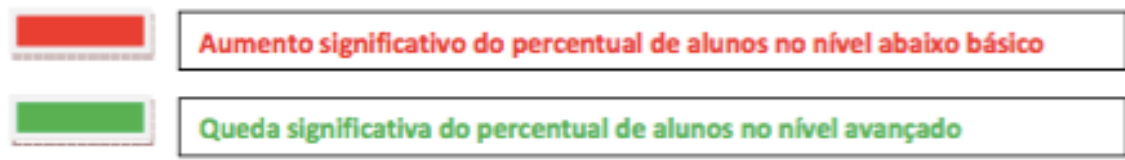

A análise dos dados da tabela que indica o nível de proficiência dos alunos avaliados na última avaliação 
externa, SARESP 2014, confirma a identificação do movimento de queda nas séries finais do Ensino Fundamental, em especial no 90 ano, tanto em Língua Portuguesa, quanto em Matemática, onde aumenta de forma significativa o percentual de alunos abaixo do básico e diminui o percentual dos que se encontram no nível avançado. Em Língua Portuguesa, no 30 ano do Ensino Fundamental, temos $88 \%$ dos alunos nível avançado, entretanto ao analisarmos o 30 ano do Ensino Médio, o percentual cai para 2,6\%. Em Matemática também não é diferente: no 30 ano do Ensino Fundamental, 76,5\% estão no nível avançado, mas no 30 ano do Ensino Médio o percentual cai para 2,6\%. Na mesma proporção também constatamos um aumento do número de alunos no nível abaixo do básico, com o passar dos anos.

\section{Avaliações e relatórios internos}

\begin{tabular}{|c|c|c|c|c|c|c|c|}
\hline Sórie/Ano & $\begin{array}{l}\text { Matriculas } \\
\text { Inlclals }\end{array}$ & Evastio & Transf. & $\begin{array}{l}\text { Matriculas } \\
\text { finnals }\end{array}$ & Disclpllinas & Aprov. & Reprov. \\
\hline \multirow{4}{*}{$1^{9}$ ano } & \multirow{4}{*}{33} & \multirow{4}{*}{0} & \multirow{4}{*}{1} & \multirow{4}{*}{32} & Linguagens & 32 & 0 \\
\hline & & & & & Matemática & 32 & 0 \\
\hline & & & & & $\begin{array}{l}\text { Ciências } \\
\text { Humanas }\end{array}$ & 32 & 0 \\
\hline & & & & & $\begin{array}{c}\text { Ciências da } \\
\text { Natureza }\end{array}$ & 32 & 0 \\
\hline \multirow{4}{*}{$2^{9}$ ano } & \multirow{4}{*}{31} & \multirow{4}{*}{0} & \multirow{4}{*}{1} & \multirow{4}{*}{30} & Linguagens & 29 & 1 \\
\hline & & & & & Matemática & 29 & 1 \\
\hline & & & & & $\begin{array}{l}\text { Ciências } \\
\text { Humanas }\end{array}$ & 29 & 1 \\
\hline & & & & & $\begin{array}{l}\text { Ciências da } \\
\text { Natureza }\end{array}$ & 29 & 1 \\
\hline \multirow{4}{*}{$3^{9}$ ano } & \multirow{4}{*}{34} & \multirow{4}{*}{0} & \multirow{4}{*}{0} & \multirow{4}{*}{34} & Linguagens & 32 & 2 \\
\hline & & & & & Matemática & 33 & 1 \\
\hline & & & & & $\begin{array}{l}\text { Ciências } \\
\text { Humanas }\end{array}$ & 32 & 2 \\
\hline & & & & & $\begin{array}{l}\text { Ciências da } \\
\text { Natureza }\end{array}$ & 32 & 2 \\
\hline \multirow{4}{*}{$4^{2}$ ano } & \multirow{4}{*}{32} & \multirow{4}{*}{0} & \multirow{4}{*}{1} & \multirow{4}{*}{31} & Linguagens & 31 & 0 \\
\hline & & & & & Matemática & 31 & 0 \\
\hline & & & & & $\begin{array}{l}\text { Ciências } \\
\text { Humanas }\end{array}$ & 31 & 0 \\
\hline & & & & & $\begin{array}{l}\text { Ciéncias da } \\
\text { Natureza }\end{array}$ & 31 & 0 \\
\hline \multirow{2}{*}{$5^{9}$ ano } & \multirow{2}{*}{35} & \multirow{2}{*}{0} & \multirow{2}{*}{0} & \multirow{2}{*}{35} & Linguagens & 34 & 1 \\
\hline & & & & & Matemática & 34 & 1 \\
\hline
\end{tabular}




\begin{tabular}{|c|c|c|c|c|c|c|c|}
\hline & & & & & $\begin{array}{l}\text { Ciências } \\
\text { Humanas }\end{array}$ & 34 & 1 \\
\hline & & & & & $\begin{array}{l}\text { Ciências da } \\
\text { Natureza }\end{array}$ & 35 & 0 \\
\hline Sórie/Ano & $\begin{array}{l}\text { Matriculas } \\
\text { Iniclals }\end{array}$ & Evastio & Transt. | & $\begin{array}{l}\text { Matriculas } \\
\text { finals }\end{array}$ & | Discipllinas | & Aprov. & Reprov. \\
\hline \multirow{8}{*}{$6^{9}$ ano } & \multirow{8}{*}{31} & \multirow{8}{*}{0} & \multirow{8}{*}{0} & \multirow{8}{*}{31} & Português & 31 & 0 \\
\hline & & & & & Matemática & 31 & 0 \\
\hline & & & & & História & 31 & 0 \\
\hline & & & & & Geografia & 31 & 0 \\
\hline & & & & & Ciências & 31 & 0 \\
\hline & & & & & L. Estrangeira & 31 & 0 \\
\hline & & & & & Ed. Fisica & 31 & 0 \\
\hline & & & & & Arte & 31 & 0 \\
\hline \multirow{8}{*}{$7^{9}$ ano } & \multirow{8}{*}{32} & \multirow{8}{*}{0} & \multirow{8}{*}{2} & \multirow{8}{*}{30} & Português & 30 & 0 \\
\hline & & & & & Matemática & 30 & 0 \\
\hline & & & & & História & 30 & 0 \\
\hline & & & & & Geografia & 30 & 0 \\
\hline & & & & & Ciências & 30 & 0 \\
\hline & & & & & L. Estrangeira & 30 & 0 \\
\hline & & & & & Ed. Fisica & 30 & 0 \\
\hline & & & & & Arte & 30 & 0 \\
\hline \multirow{8}{*}{$8^{2}$ ano } & \multirow{8}{*}{33} & \multirow{8}{*}{0} & \multirow{8}{*}{0} & \multirow{8}{*}{33} & Português & 33 & 0 \\
\hline & & & & & Matemática & 33 & 0 \\
\hline & & & & & História & 33 & 0 \\
\hline & & & & & Geografia & 33 & 0 \\
\hline & & & & & Ciências & 33 & 0 \\
\hline & & & & & L. Estrangeira & 33 & 0 \\
\hline & & & & & Ed. Fisica & 33 & 0 \\
\hline & & & & & Arte & 33 & 0 \\
\hline \multirow{8}{*}{$9^{9}$ ano } & \multirow{8}{*}{29} & \multirow{8}{*}{01 morte } & \multirow{8}{*}{0} & \multirow{8}{*}{28} & Português & 28 & 0 \\
\hline & & & & & Matemática & 28 & 0 \\
\hline & & & & & História & 28 & 0 \\
\hline & & & & & Geografia & 28 & 0 \\
\hline & & & & & Ciências & 28 & 0 \\
\hline & & & & & L. Estrangeira & 28 & 0 \\
\hline & & & & & Ed. Fisica & 28 & 0 \\
\hline & & & & & Arte & 28 & 0 \\
\hline \multirow{4}{*}{$\begin{array}{c}1^{9} \text { ano } \\
\text { E.M. }\end{array}$} & \multirow{4}{*}{32} & \multirow{4}{*}{0} & \multirow{4}{*}{3} & \multirow{4}{*}{29} & Português & 29 & 0 \\
\hline & & & & & Matemática & 29 & 0 \\
\hline & & & & & História & 29 & 0 \\
\hline & & & & & Geografia & 29 & 0 \\
\hline
\end{tabular}




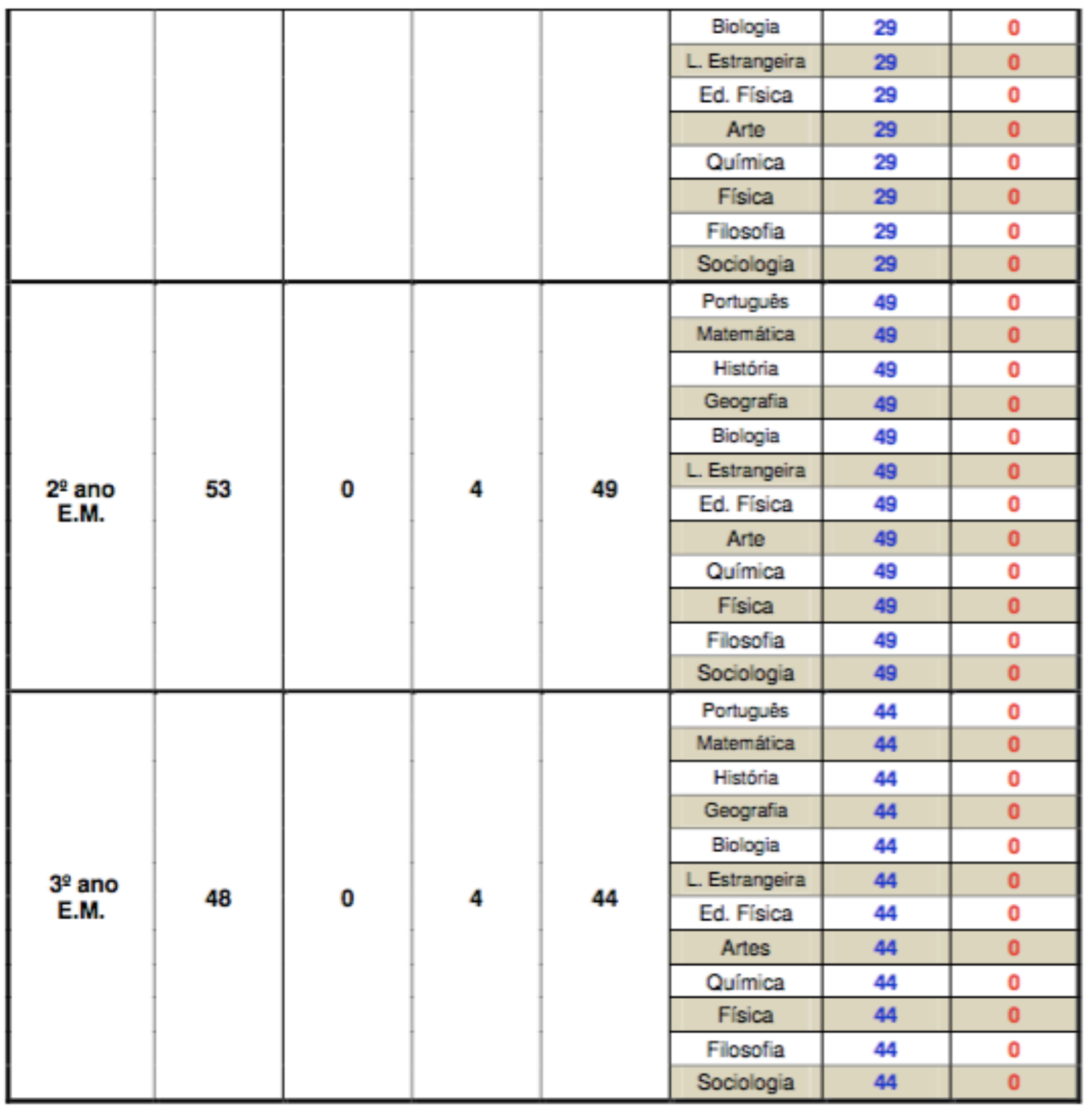

Considerando o reconhecimento da família e comunidade pela excelente qualidade de ensino oferecida pela escola, o percentual de transferência durante 0 ano é pequeno, e ainda em sua maioria por mudança de município. Quanto à evasão, também o índice é zero, tivemos apenas uma por motivo de morte. A tabela nos aponta então uma atenção da equipe gestora quanto ao índice de $100 \%$ de aprovação do Ensino Fundamental II e Ensino Médio, como já mencionamos anteriormente, pois são nesses anos que a escola apresenta queda nos resultados de aprendizagem na avaliação externa. Na medida em que se deseja uma escola que atenda às atuais exigências da vida social: formar cidadãos oferecendo ainda a possibilidade de apreensão de competências e habilidades necessárias e facilitadoras da inserção social, estaremos mobilizando e articulando todos os recursos materiais e humanos necessários para a melhoria dos resultados de aprendizagens dos alunos. Provocar reflexões sobre os problemas levantados e juntos buscarmos as possíveis soluções é o caminho que escolhemos, pois se não houver sentimento de pertença e a corresponsabilidade pelos resultados de aprendizagem dos alunos, não conseguiremos atingir 0 nosso objetivo.

A proposta de uma gestão democrática e participativa tem contribuído muito para as tomadas de decisão. Procuramos ainda envolver pais e alunos nos Conselhos de Classe participativos, quando os mesmos são 
convidados e incentivados à participação, tanto apresentando problemas, como sugerindo soluções. A liberdade de manifestação com responsabilidade, muito contribui para o cumprimento das regras e combinados, em situações que afetam a rotina da escola, o que interfere positivamente no processo ensino e aprendizagem.

\section{Principais problemas identificados}

1- Baixa participação dos pais a partir do 60 ano do ensino fundamental II, diminuindo significativamente no Ensino Médio;

2- Queda dos resultados na avaliação externa nos anos finais do Ensino Fundamental;

3- Ausência de compromisso da equipe docente no processo avaliativo, com aprovação em massa dos anos em que a escola apresenta queda nos resultados na avaliação externa;

4- Maior índice de absenteísmo dos professores que trabalham com as salas do Ensino Fundamental II e Ensino Médio.

\begin{tabular}{|c|c|c|c|c|c|}
\hline Problemas & G & U & T & GxUxT & Prioridade \\
\hline Problema 1 & 3 & 4 & 5 & 60 & $3^{\circ}$ \\
\hline Problema 2 & 5 & 5 & 5 & 125 & $1^{\circ}$ \\
\hline Problema 3 & 5 & 5 & 5 & 125 & $1^{9}$ \\
\hline Problema 4 & 5 & 4 & 4 & 80 & $2^{9}$ \\
\hline
\end{tabular}

\section{Detalhamento do problema}

Utilizou-se o Diagrama de Causa e Efeito para detalhar o problema:

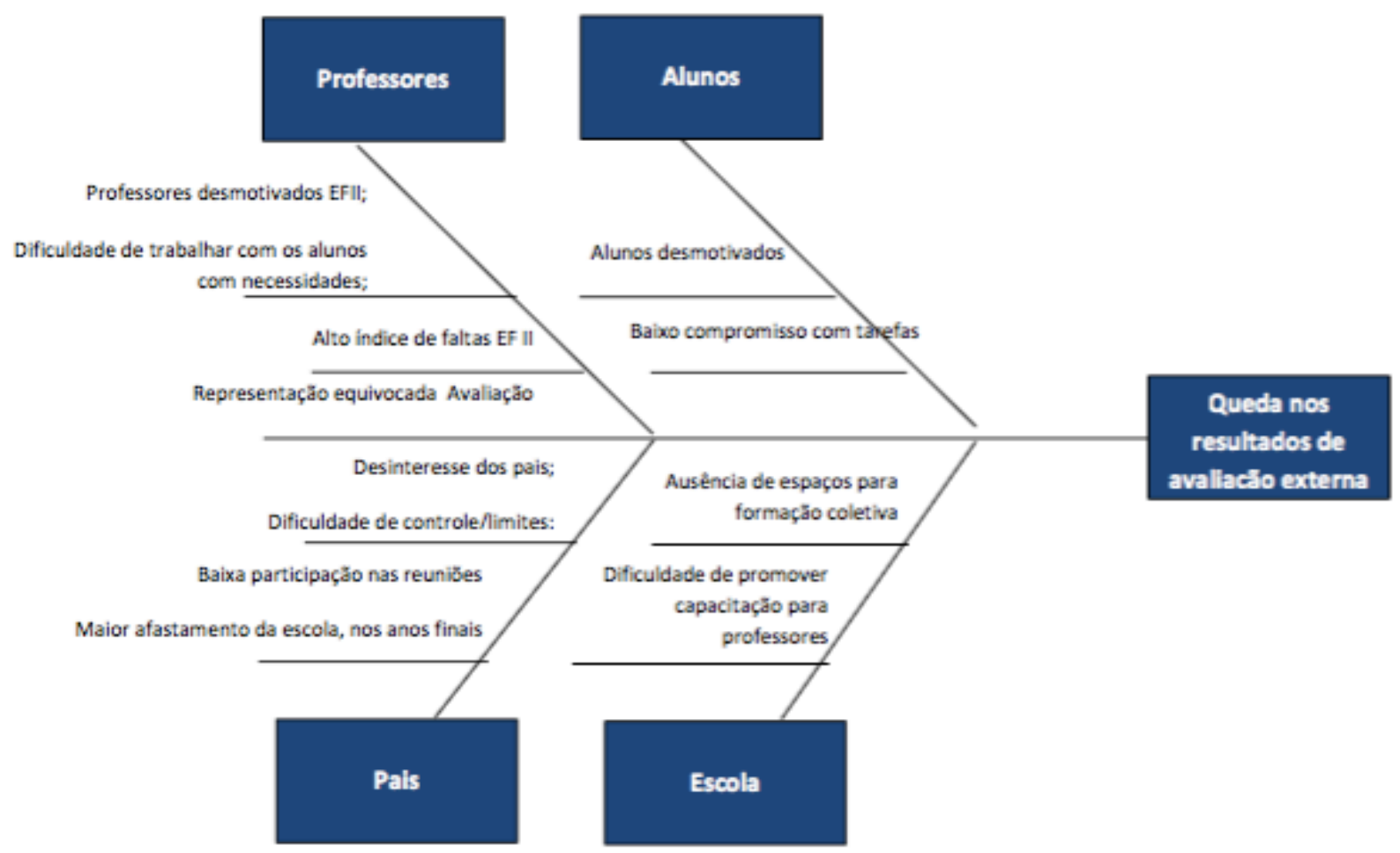




\section{Análise SWOT}

A partir das pesquisas realizadas pela equipe escolar e das discussões sobre o contexto da escola, foi desenvolvida a seguinte Matriz SWOT:

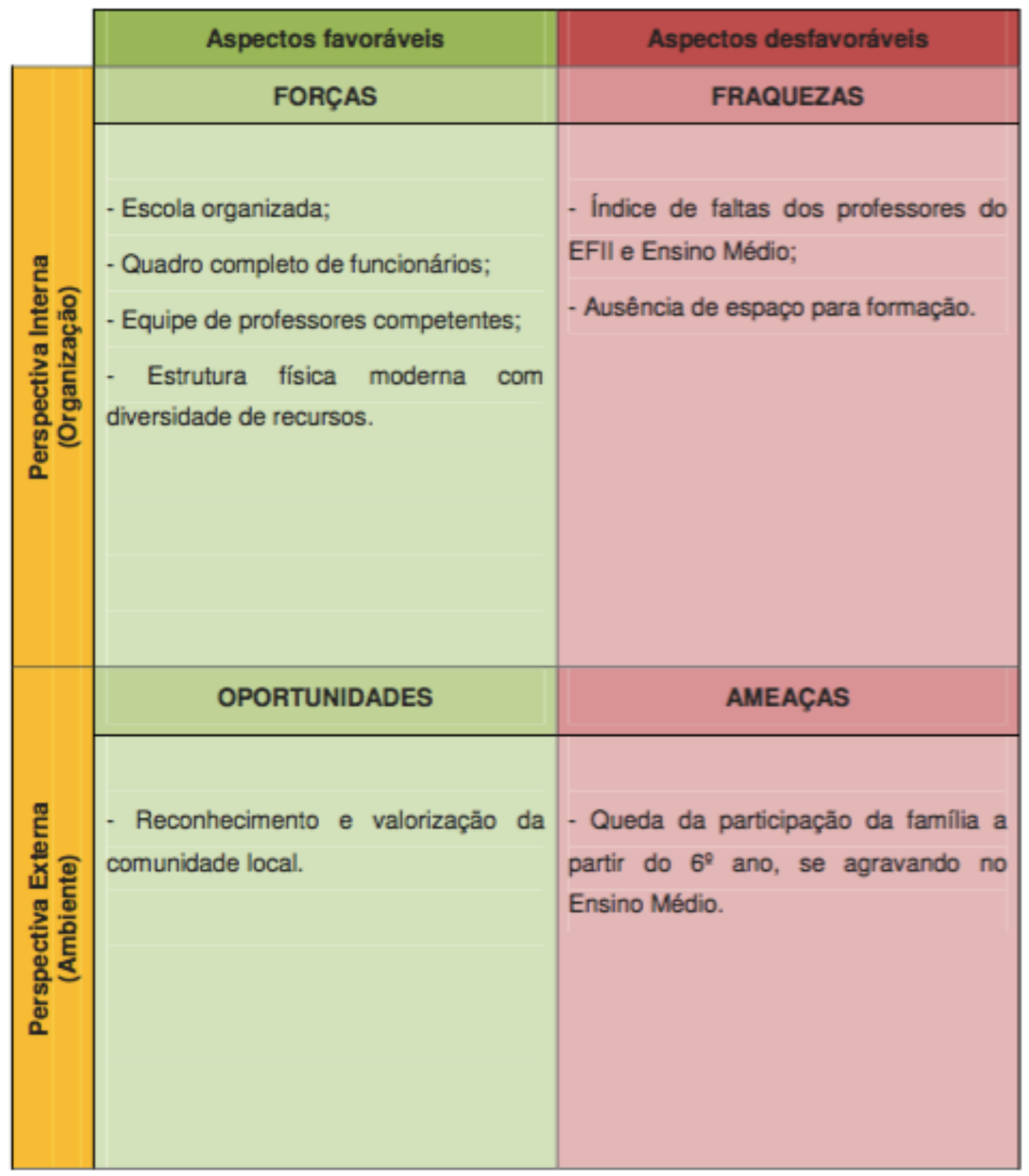

Analisando a matriz inferimos que a escola possui forças e possibilidades essenciais para o desenvolvimento de um projeto educativo que impacte positivamente na ação docente, e consequentemente nos resultados de aprendizagens dos alunos. Quanto às fraquezas e as ameaças, se bem trabalhadas, com ações exequíveis, são passíveis de transformação.

\section{Ações corretivas}

Visando preparar a organização para o desenvolvimento do projeto, no intuito de combater as fraquezas e reduzir os possíveis impactos das ameaças, foram definidas as seguintes ações:

Monitoramento das faltas dos professores;

Trabalho de conscientização com foco no prejuízo pedagógico que as faltas estão causando;

Valorização e reconhecimento dos professores que apresentam menor número de faltas;

Busca de estratégias para desenvolver e garantir momentos de formação coletiva; 
Reuniões de pais tematizadas; Convites nominais aos pais para participação das reuniões; Mudança de horário de reunião para viabilizar a participação dos pais.

\section{Oportunidade identificada}

A ideia central da proposta é o resgate do profissionalismo docente e sua identidade. 0 professor, apesar de ter conhecimento do seu papel na formação do cidadão, como também para a transformação da sociedade, tem se apresentado desmotivado frente a este desafio. A desvalorização da sociedade, como também a ausência de parceria da família interferem diretamente neste sentimento, que contribuem para 0 enfraquecimento deste tão importante profissional.

Espera-se que o desenvolvimento de um projeto que enfoque o fortalecimento do professor como profissional, interfira diretamente na sua ação em sala de aula. Este projeto formativo deverá abordar as diferentes dimensões da atuação docente: técnica, relacional, social e profissional.

A análise do profissionalismo docente, e o modo como este profissional tem sido afetado ao longo dos tempos, requer não só a compreensão do trabalho dos professores e como estes se veem enquanto profissionais, e ainda como a sociedade os veem, como também a consideração do contexto - social, político e cultural - em que se inscreve, dado que se trata de um conceito que não é estático, mas antes dinâmico e contextualizado.

Considerando que é na escola o lugar onde os professores constroem e fortalecem a sua profissionalidade, como gestores, somos responsáveis por encontrar meios para garantir que este espaço privilegiado, seja de educação permanente para os docentes. A qualidade da educação está diretamente ligada ao profissionalismo docente, portanto se vislumbramos elevar os resultados de aprendizagem dos alunos, precisamos investir em ações para o reconhecimento social e cultural desta nobre profissão.

\section{Detalhamento do produto/serviço elou processo}

Foco do projeto Série ou conjunto de séries beneficiadas: Ensino Fundamental II e Ensino Médio

Disciplina ou conjunto de disciplinas trabalhadas: Todos os componentes curriculares.

\section{Etapas do projeto}

O projeto será composto pelas seguintes etapas:

\section{Etapa 1 - Mobilização}

Objetivo: Mobilizar os docentes para a importância da participação nos encontros de formação.

Impacto na aprendizagem: 0 interesse dos alunos está relacionado á motivação dos professores. Quanto maior o interesse dos alunos, melhor a aprendizagem.

Atividades a serem realizadas:

\section{Atividade 1.1}

Descrição: O convite à participação do primeiro encontro de formação cujo tema é " A Identidade do Professor e a reconstrução da Profissão Docente" será nominal, e constará a programação com as atividades do dia, que serão dinâmicas e ao mesmo tempo leves, com objetivo de "seduzi-los". Tanto no primeiro, como nos demais encontros, os professores participarão de dinâmicas, palestras com profissionais de diferentes áreas, de discussões em pequenos grupos, e de oficinas que lhes oportunizarão refletir, agir e tomar de decisão.

Este primeiro encontro tem como objetivos:

- Refletir sobre as características essenciais de uma ocupação para que possa ser designada de profissão;

- resgatar a autoestima do profissional professor, partindo do princípio que sua formação lhe faculta o domínio do conhecimento especializado da sua disciplina, como também a competência para trabalhar com os 
estudantes e contribuir para a sua formação cidadã;

- fortalecer a autonomia do professor para as tomadas de decisão em sala de aula, espaço privilegiado para a reconstrução do seu profissionalismo docente.

Duração: 4 horas Recursos necessários: Datashow, mesas redondas, notebooks, flipshart.

Equipe envolvida: Equipe gestora, professores e psicólogo especialista em recursos humanos.

Por esta atividade ser a primeira, portanto na etapa de mobilização, espera-se que os professores saiam deste encontro com a autoestima elevada, e fortalecida quanto à importância do seu papel para a construção de uma sociedade mais justa, igualitária, consciente e honesta. Que ainda sintam-se acolhidos, valorizados e com vontade de retornar e dar continuidade ao projeto formativo.

\section{Atividade 1.2}

Descrição: Neste segundo momento, ainda na etapa de mobilização, o tema escolhido para trabalhar com os docentes está relacionado aos aspectos comportamentais: "Cultura, Clima organizacional e as Relações Interpessoais", que tem por objetivos:

- Propiciar momentos de comunicação e integração no grupo; - Identificar barreiras na comunicação; - Propor ações para amenizar as barreiras identificadas. - Favorecer uma experiência de percepção em relação ao outro; Duração: 4 horas

Recursos necessários: Sala ampla que possibilite movimentação dos grupos para as dinâmicas, Datashow, mesas redondas, revistas, papel Kraft e pincéis coloridos.

Equipe envolvida: Equipe gestora, professores, administrador de empresas com especialização em comunicação.

\section{Etapa 2 - Construção}

Objetivo: Identificar os desafios da sociedade atual com relação à constituição da autoria e da autonomia do professor em sala de aula.

Impacto na aprendizagem: 0 protagonismo docente favorece a mediação entre o saber e 0 aluno, porque é esperado do professor que através de ações de ensino bem planejadas obtenha bons resultados de aprendizagem com seus alunos.

Atividades a serem realizadas:

\section{Atividade 2.1}

Descrição: Nesta etapa os professores e funcionários serão convidados a trabalhar em pequenos grupos para pensarem em ações que contribuam para o resgate do profissionalismo docente na comunidade escolar. Após a construção nos pequenos grupos o mediador proporá a socialização para a elaboração de um Plano Coletivo.

Duração: 4 horas

Recursos necessários: Datashow, mesas redondas, notebooks com acesso á internet para um trabalho de pesquisa, flipshart.

Equipe envolvida: Equipe Gestora, professores, Inspetores de Alunos, Bibliotecário e equipes de apoio.

\section{Atividade 2.2}

Descrição: Nesta 2a etapa de construção da Identidade e Profissionalismo docente, representantes dos alunos, dois por sala, do 60 ano do Ensino Fundamental ao 30 ano do Ensino Médio, um pai de cada uma das salas e também os demais funcionários da escola serão convidados a participar do encontro com os professores com objetivo de dar voz aos diferentes atores do processo ensino e aprendizagem. Após um momento de sensibilização feito por um profissional da educação, especialista em gestão educacional, os participantes serão divididos em grupos intencionais, de forma que nos mesmos tenha representante do 
corpo docente, do corpo discente e de pais, para pensarem nas diferentes variáveis que impactam de forma negativa na aprendizagem dos alunos do 60 ano do Ensino Fundamental ao 30 ano do Ensino Médio e em seguida apresentarem sugestões em forma de ações que contribuam para a melhoria do processo ensino e aprendizagem. Essas ações deverão ser socializadas no grande grupo para validação e inserção no Plano de Melhoria.

Duração: 04 horas Recursos necessários: Datashow, mesas redondas, notebooks, flipshart.

Equipe Envolvida: Equipe Gestora, professores, funcionários, pais, alunos e um pedagogo especialista em gestão.

\section{Atividade 2.3}

Descrição: Após reflexão, discussão e construção coletiva sobre as diferentes variáveis que perpassam diferentes dimensões, como: clima escolar; relações interpessoais entre os sujeitos do processo; postura profissional; prática pedagógica e gestão do currículo, toda equipe será presenteada com um encontro com a filósofa Viviane Mosé, que abordará o tema: "Ética, Valores e Cidadania na Escola e os Desafios Contemporâneos." Nesta abordagem a filósofa conduzirá a equipe a uma análise crítica sobre o modelo de escola atual, quando a classifica como uma escola abstrata, que unida à sua característica de escola fragmentada, segmentada, passiva, isolada da sociedade, é constituída por relações hierárquicas, onde 0 estudante é a parte que tem que respeitar, mas que muitas vezes não é respeitado. Apresentará o cenário em que estamos vivendo, um imenso desenvolvimento tecnológico, e ao mesmo tempo uma imaturidade político social de mesma amplitude, com uma nova geração que lida muito bem com a complexidade da informatização, da globalização, enquanto a escola permanece segmentada. Apresentará uma proposta de reconstrução de uma escola que não valorize somente a palavra e a ideia abstrata, mas que passe a valorizar a vivência, contextualizando o seu ensino, aberta para a cultura e para a arte. A escola como um espaço alegre, pois a ludicidade da arte, torna as dificuldades mais fáceis, e favorece a compreensão sobre o que é a ética na prática. A arte envolve o respeito à produção própria e à do outro, a valorização das peculiaridades, do modo de ver de cada um, entre outros. Viviane falará com a equipe durante noventa minutos e após um intervalo farão pequenas rodas de conversa para discussão e elaboração de questões que serão trazidas para a filósofa no momento de interação. Esta proposta tem como objetivo ampliar o pensamento e 0 repertório para a sistematização do Plano de Melhoria.

Duração: 4 horas Recursos necessários: Recursos audiovisuais, sala ampla.

Equipe envolvida: Equipe gestora, funcionários, professores, e a filósofa Viviane Mosé, psicóloga e psicanalista formada pela Universidade Federal do Espírito Santo. Mestre e Doutora em filosofia pelo Instituto de Filosofia e Ciências Sociais na Universidade Federal do Rio de Janeiro.

\section{Etapa 3 - Sistematização}

Objetivo: Sistematizar o Plano de Melhoria considerando as ações trabalhadas nos encontros anteriores, registrando prazos e responsáveis por cada ação.

Impacto na aprendizagem: A construção de um Plano que permite a participação de todos os autores envolvidos no processo responsabiliza-os ao cumprimento do que foi planejado. É o sentimento de pertença que foi estabelecido ao longo dos encontros, quanto maior o envolvimento, maior o comprometimento.

Atividades a serem realizadas:

\section{Atividade 3.1}

Descrição: Nesta etapa, toda a equipe mais fortalecida, com o pensamento e o repertório ampliado, com os indicadores em mãos, sistematizará o Plano de Melhoria. Para este encontro convidamos o professor Luiz Marins que é Consultor e Conselheiro de empresas e organizações nacionais e internacionais, para falar com a equipe sobre "O planejamento e o trabalho em Equipe." O objetivo é de mobilização para a importante tarefa que têm pela frente, como também maior embasamento para a sistematização do Plano. Após a apresentação do professor Luiz Marins, a equipe se reunirá em pequenos grupos para o registro e em 
seguida em grande grupo a socialização e sistematização.

Duração: 4 horas Recursos necessários: Recursos audiovisuais, notebooks, mesas redondas.

Equipe envolvida: Equipe gestora, funcionários, professores, e o professor Luiz Marins.

\section{Etapa 4 - Finalização do Projeto e Implantação do Plano de Melhoria}

\section{Atividade 4.1}

Descrição: É chegado o momento da apresentação do Projeto finalizado para que todos comecem colocar em prática. Após seis encontros que oportunizaram muita reflexão referente à profissionalidade e ao protagonismo docente, buscando fortalecer a autonomia deste profissional da educação, entende-se que este valor agregado muito contribuirá para a mudança da prática e para a melhoria das relações no ambiente escolar, que impactará diretamente no processo ensino e aprendizagem, elevando o índice dos resultados dos alunos. Antes da apresentação, pelo Diretor da Escola, do projeto finalizado, toda a equipe será presenteada com uma palestra de sensibilização ministrada pelo professor Celso Vasconcellos, Doutor em Educação pela Universidade de São Paulo, mestre em História e Filosofia da Educação pela Pontifícia Universidade Católica de São Paulo, que abordará o tema Planejamento com enfoque na implantação do Plano de Ação construído no coletivo. A abordagem do palestrante será de noventa minutos, dividido entre fala e a interatividade com o grupo. Em seguida, o Diretor apresentará o Plano de Melhoria, como também a forma de Avaliação e Monitoramento das ações nele contidas. Todos os participantes receberão uma cópia do Plano, para que as ações sejam garantidas e consideradas, tanto no momento da elaboração do Plano de Trabalho Docente, como no movimento da aula e das atividades da escola, em todas as suas dimensões.

\section{Duração: 4 horas}

Recursos necessários: Recursos audiovisuais cópias do Plano de Melhoria a todos os profissionais da escola.

Equipe envolvida: Equipe Gestora, professores, Inspetores de Alunos, Bibliotecário e equipes de apoio e 0 professor convidado, Celso Vasconcellos.

\section{Atividade 4.2}

Descrição: Na segunda quinzena de agosto, após o projeto ter sido apresentado à equipe de professores e funcionários, o encerramento com a presença de representantes de pais, alunos e autoridades do município, na quadra da escola. $O$ Diretor da escola apresentará as várias etapas vivenciadas nas sete manhãs de sábado de formação, desde à mobilização, construção até a sistematização coletiva do Plano de Melhoria, a fim de evidenciar a importância e a riqueza deste projeto para elevar os resultados de aprendizagem dos alunos. Após a apresentação haverá depoimentos de alunos, pais, funcionários e professores que participaram desta construção, manifestando seu sentimento em relação ao que foi apresentado e a importância da sua contribuição.

Todos serão presenteados com a apresentação da Orquestra Bachiana do SESI, sob a condução do maestro João Carlos Martins, encerrando com um coquetel de confraternização, servido pelo Buffet J Souza da cidade de Araçatuba.

Duração: 03 horas Recursos: Datashow, montagem de som, palco, cadeiras , aparadores, mesas bistrô.

Equipe envolvida: Toda equipe da escola, representantes de pais, alunos, autoridades e Orquestra Bachiana.

\section{Casos de sucesso}

Nome do Projeto: Ciclo Virtuoso e Transformador Nome da organização: EMEF - Nossa Senhora de Guadalupe Local: Concórdia - Pará Período em que foi realizado: De 2005 a 2010 Breve relato do contexto anterior ao projeto: Até o começo de 2005, as únicas famílias que matriculavam os filhos na EMEF Nossa Senhora de Guadalupe, em Concórdia do Pará, a 152 quilômetros de Belém, eram as que não conseguiam vaga em outra escola da cidade. Ao mesmo tempo, quem entrava para a equipe docente escutava: "Vai para a Guadalupe? Coitado. Um lugar tão ruim..." O Índice de Desenvolvimento da Educação Básica (Ideb) era de apenas 2, o pior do município. Em 2005, Francisco Charles Martins de Souza e Fumi Hosoda Mineshita 
assumiram, respectivamente, a direção e a vice-direção da EMEF Nossa Senhora de Guadalupe. De cara, perceberam que precisariam mudar a imagem ruim que as famílias tinham da escola - tanto em relação à estrutura física quanto à sua organização interna. Era urgente reformar a escola: o pátio servia de estacionamento para motos e bicicletas; não havia espaços de convivência protegidos do sol nem sala de informática e biblioteca; faltavam salas de aula; e os professores se reuniam na cozinha. Os recursos do governo não eram suficientes e ao buscar apoio dos comerciantes e empresários, os gestores viram o quanto a instituição estava desacreditada. Muitos desconfiavam do destino das doações feitas anteriormente - não havia prestação de contas nem melhorias aparentes. A equipe gestora pediu um voto de confiança, conseguiu verbas e materiais e organizou mutirões. Ao final de cada reforma, apresentavam à comunidade, em planilhas, tudo o que foi arrecadado e como foi gasto.

Resumo dos principais resultados alcançados: Hoje, quase sete anos depois, os pais fazem fila em busca de matrícula nessa mesma escola. Ou melhor, nessa escola, que não é mais a mesma. Os professores que lá trabalham agora recebem os parabéns. E o Ideb dobrou. Quando a escola estava em estado de abandono, os alunos não a viam como um lugar de aprendizagem. Para as famílias, a instituição servia a propósitos como oferecer merenda. Professores e funcionários faltavam por qualquer motivo. Contudo, as novas benfeitorias mostraram que a gestão se tornara séria e todos se sentiram mais valorizados. Hoje, quem entra na Guadalupe é recebido por crianças e jovens entusiasmados, que não se cansam de dizer que não trocam a escola por outra. Os pais reconhecem o valor do ensino, são atuantes no Conselho Escolar e fazem fila na época de matrículas. $E$ os docentes e a equipe de apoio recebem formação permanente e se comprometem cada vez mais.

Com a imagem recuperada e a comunidade motivada, o impacto na aprendizagem logo surgiu. Entre $2005 \mathrm{e}$ 2010, a aprovação subiu de $54 \%$ para $75 \%$. No mesmo período, o Ideb das turmas de 4 a série saltou de 2 para 3,9. E das turmas de 8 a série subiu de 2,5 em 2007, quando começou a ser medido na escola, para 4,1, em apenas dois anos. "Para continuar crescendo, temos novos projetos, como uma rádio interna, comandada pelos alunos", conta o diretor. A evasão ainda preocupa - apesar de ter caído de $17 \%$ para $14 \%$ nos últimos anos -, em especial na Educação de Jovens e Adultos (EJA). Para incluir a EJA no ciclo virtuoso, as turmas da noite ganharam um coordenador pedagógico exclusivo e inovações no currículo, como um projeto de saúde em Educação Física e uma oficina de escrita.

Fonte: http://revistaescola.abril.com.br

\section{Novidade trazida pelo projeto}

A queda dos resultados de aprendizagem a partir do 60 ano do Ensino Fundamental é constada na grande maioria das escolas de Educação Básica, que têm buscado melhorar os resultados com ações pontuais voltadas para as dificuldades dos alunos, em especial nos componentes avaliados: Língua Portuguesa e Matemática. Em nossa escola as ações também sempre foram pensadas no nível de melhoria de desempenho dos alunos, com atividades voltadas para as dificuldades nos componentes indicados e avaliações constantes para monitorar os resultados. Este monitoramento vem nos indicando que somente as estas ações voltadas para retomada de conteúdos com base nas dificuldades não estão atingindo as metas estipuladas pela equipe, que a cada ano vem se apresentando desmotivada. Diante desta análise, pensamos em um projeto que tivesse relação mais direta com a formação do professor, este profissional que ao longo dos anos vem perdendo sua identidade. 0 professor vem enfrentando muitas dificuldades no exercício de sua função, as quais refletem diretamente na crise de autoridade e de poder do mesmo. Considerando que uma das bases históricas fundamentais para que o professor consiga o reconhecimento da sua autoridade é a ampliação do seu repertório de conhecimento e o domínio metodológico do processo educativo, que o projeto foi pensado numa dimensão pessoal que não pode ser esquecida ou desvalorizada. Quanto à novidade trazida pelo projeto, é de caráter incremental, pois traz aperfeiçoamento à formação que já existe, porém com outro foco. Não traz novidades para a sociedade, pois formação docente é a tônica da maioria das instituições de ensino, mas é inovador para a escola, considerando o resgate da profissionalidade docente.

\section{Cronograma de execução}


O projeto será desenvolvido em sete sábados, o primeiro de cada mês indicado no cronograma abaixo.

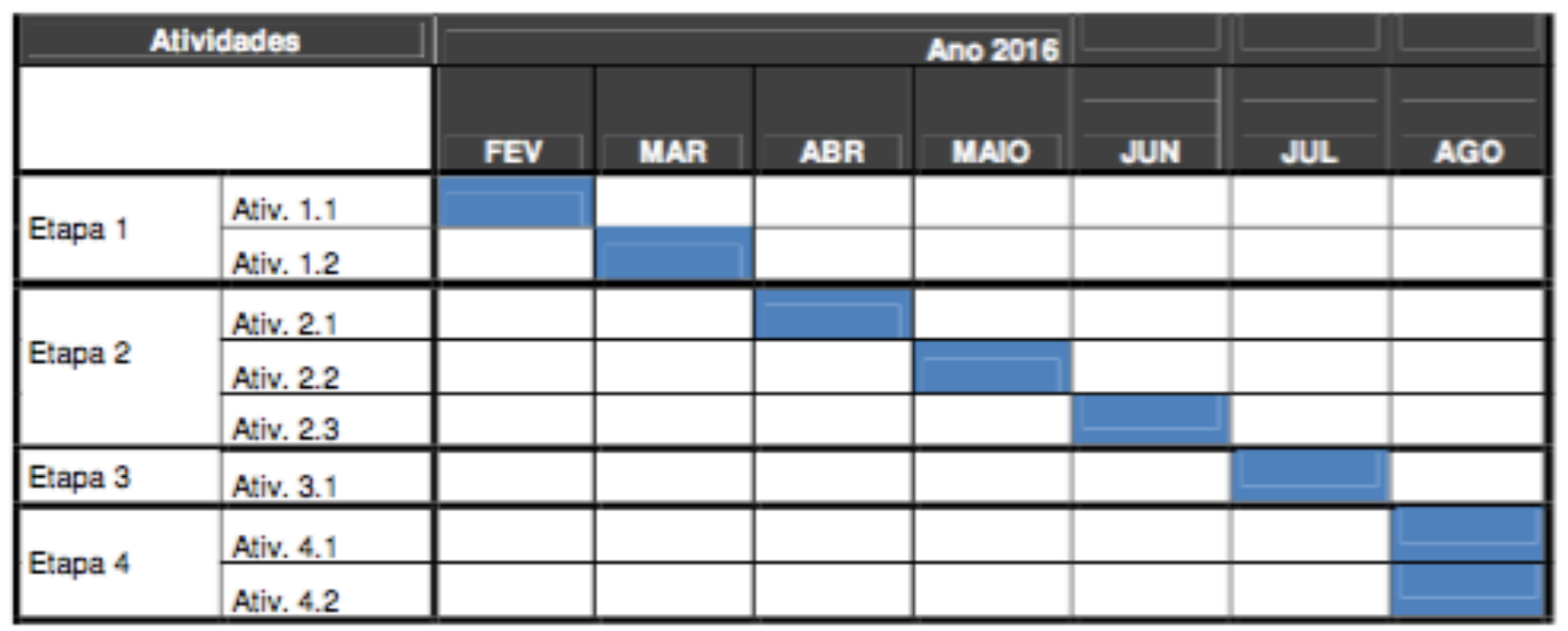

\section{GESTÃO ESTRATÉGICA}

Objetivos estratégicos

\begin{tabular}{|c|c|c|c|}
\hline Objetivos & Metas & Indicadores & Acompanhamento \\
\hline $\begin{array}{l}\text { Ampliar o } \\
\text { debate sobre a } \\
\text { qualidade do } \\
\text { trabalho escolar } \\
\text { para que a } \\
\text { escola possa } \\
\text { cumprir com a } \\
\text { finalidade que } \\
\text { se destina. }\end{array}$ & $\begin{array}{l}\text { Elevar a autoestima da } \\
\text { equipe docente, fortalecer o } \\
\text { papel do professor como } \\
\text { agente transformador. } \\
\text { Fortalecer o vínculo da } \\
\text { família com a escola, } \\
\text { enfatizando a importância } \\
\text { da parceria para a melhoria } \\
\text { dos resultados. }\end{array}$ & $\begin{array}{c}\text { Participação dos } \\
\text { professores nas } \\
\text { atividades } \\
\text { promovidas pela } \\
\text { escola; } \\
\text { Resultados de } \\
\text { aprendizagem } \\
\text { nas avaliaçōes } \\
\text { internas; } \\
\text { Planilhas de } \\
\text { atividades extra- } \\
\text { classe; } \\
\text { Planilha de } \\
\text { participação dos } \\
\text { pais nas } \\
\text { atividades } \\
\text { promovidas pela } \\
\text { escola; } \\
\text { Planilha de } \\
\text { ocorrências em } \\
\text { sala de aula; } \\
\text { Número de fale } \\
\text { conosco } \\
\text { referente ao } \\
\text { trabalho } \\
\text { pedagógico. }\end{array}$ & $\begin{array}{l}\text { Acompanhamento in loco da } \\
\text { dinâmica das aulas; } \\
\text { Análise de Feedback de } \\
\text { alunos e professores; } \\
\text { Análise do clima da escola, } \\
\text { considerando o nível de } \\
\text { entrosamento de todos os } \\
\text { autores. } \\
\text { Análise da pesquisa de } \\
\text { satisfação aplicada aos pais e } \\
\text { alunos. }\end{array}$ \\
\hline
\end{tabular}




\begin{tabular}{|c|c|c|c|}
\hline $\begin{array}{c}\text { Reconstruir a } \\
\text { profissionalidade } \\
\text { e protagonismo } \\
\text { docente. }\end{array}$ & $\begin{array}{l}\text { Diminuir os índices de } \\
\text { absenteísmo docente em } \\
20 \%\end{array}$ & $\begin{array}{l}\text { Planilha de } \\
\text { controle de } \\
\text { faltas. }\end{array}$ & $\begin{array}{l}\text { Monitoramento das faltas e } \\
\text { dos motivos apresentados. }\end{array}$ \\
\hline $\begin{array}{l}\text { Construir um } \\
\text { Plano de } \\
\text { Melhoria com } \\
\text { açōes que } \\
\text { possibilitem } \\
\text { elevar os } \\
\text { resultados de } \\
\text { aprendizagem } \\
\text { dos alunos a } \\
\text { partir do } 6^{2} \text { ano } \\
\text { do Ensino } \\
\text { Fundamental }\end{array}$ & $\begin{array}{c}\text { Alcançar a meta } \\
\text { estabelecida pela Divisão } \\
\text { de Educação nas } \\
\text { Avaliaçōes Externas }\end{array}$ & $\begin{array}{l}\text { Resultados das } \\
\text { Avaliaçōes } \\
\text { Externas e } \\
\text { Internas }\end{array}$ & $\begin{array}{l}\text { Controle do rendimento das } \\
\text { turmas, por etapa e definição } \\
\text { de açōes corretivas. }\end{array}$ \\
\hline
\end{tabular}

\section{Continuidade do projeto}

A continuidade de um projeto implantado depende muito do monitoramento constante, avaliação e ajustes necessários durante o processo. Desta forma estarei monitorando a efetividade do projeto e a evolução das práticas a fim de identificar aspectos que demandam atenção diferenciada e replanejamento. 0 monitoramento se dará através de:

- Análise do ritmo e desdobramento de ações realizadas em cotejamento com o Plano de Melhoria; Verificação da obtenção dos resultados propostos, e quais aspectos necessitam de revisão de ações e reformulação;

- Feedbacks de pais e alunos sobre a efetividade das ações propostas; - Espelho de notas que evidenciem os avanços dos resultados de aprendizagem dos alunos; - Auto avaliação de todos os sujeitos envolvidos no processo com foco no cumprimento das ações; - Reuniões mensais com a equipe com objetivo de promover discussão coletiva sobre os avanços e as dificuldades encontradas no percurso.

\section{Marketing e Comunicação Lançamento do projeto}

Haverá dois momentos:

\section{I - Lançamento do projeto}

- O lançamento do projeto, que será a primeira atividade com a equipe gestora e os professores do Ensino Fundamental II, que após receberem convite nominal com toda a programação, inclusive cardápio de café da manhã, estratégias utilizadas para atraí- los, espera-se que sintam-se acolhidos e mobilizados à participação, uma vez que toda a programação foi pensada para a motivação. 0 profissional convidado para iniciar este trabalho deverá ser dinâmica e ao mesmo tempo sensível para levar à equipe a uma reflexão positiva sobre a profissão docente, hoje tão desgastada e desacreditada por pais e sociedade.

Neste primeiro encontro, além da parte motivacional, coordenada por psicólogo com formação em Recursos Humanos, a equipe gestora apresentará a programação dos demais encontros, objetivando despertar interesse e desejo de continuar.

\section{II - Apresentação do Plano de Melhoria construído durante o desenvolvimento do Projeto}

- A apresentação do Plano será feita à Comunidade Escolar, representantes de pais e alunos de todas às turmas, autoridades locais e educacionais, uma culminância de todas as atividades. A apresentação da orquestra e o coquetel tornará este momento festivo para a escola e comunidade. 
Canais de comunicação e acompanhamento do projeto Marketing interno A comunicação com a equipe ocorrerá de diferentes formas: - Convite individual;

- Cartazes afixados na sala dos professores e em outros espaços da escola sobre o próximo encontro (mensal);

- Envio de e mail (semanal); - Envio de mensagens por WhatsApp (semanal e na véspera do encontro);

- Postagens no facebook da escola com fotos dos encontros ocorridos e depoimentos dos participantes (mensal).

As mensagens serão enviadas semanalmente, e sempre na véspera do encontro enviaremos um recado mais diretivo, lembrando-os do nosso compromisso.

\section{Marketing externo}

Para viabilizar o marketing externo serão utilizados: - registros no site oficial da escola; - postagem no facebook; - postagem de vídeos das atividades no youtube;

- apresentação nas reuniões de pais; - apresentação em fóruns e congressos educacionais; - boletim informativo semestral da escola.

\section{Parceiros estratégicos}

Empresas Óleos Menu com patrocínio de camisetas e sacolas ecológicas com Kit (agenda, caneta e folder);

UNIALCO - Usina de Álcool da cidade com patrocínio de livros que serão sorteados nos encontros;

Rádios locais FM e AM - Divulgação do projeto e entrevista com os participantes.

Jornais Locais e Regional - Publicação de fotos e síntese dos encontros.

Como a escola é muito valorizada e reconhecida pela comunidade local, jornais e rádios sempre demonstram interesse em divulgar as atividades realizadas no espaço escolar. Portanto já existe este estabelecimento de parceria, que tem se fortalecido a cada ano, por ser interesse de ambas as partes.

\section{Divulgação de resultados}

Os resultados serão divulgados através de planilhas de monitoramento e gráficos da pesquisa de satisfação dos alunos:

- nas reuniões de pais, quadrimestrais;

- nas reuniões pedagógicas e DPCs;

- nos Murais da escola;

- nos boletins informativos semestrais.

Nos momentos de reunião coletiva os gráficos e planilhas serão avaliados e discutidos com foco no replanejamento e ajustes das ações durante o processo de implantação. 


\section{Equipe do Projeto}

\section{Equipe interna}

\begin{tabular}{|c|c|c|c|c|}
\hline Cargo & Formaçăo & $\begin{array}{c}\text { Tempo na } \\
\text { escola }\end{array}$ & Experiência anterior & \begin{tabular}{|c|} 
Responsável \\
pelas \\
atividades: \\
\end{tabular} \\
\hline $\begin{array}{l}\text { Diretor da } \\
\text { Escola }\end{array}$ & $\begin{array}{l}\text { Pedagogia, Letras } \\
\text { e Administração de } \\
\text { Empresas - Mestre } \\
\text { em Educaçăo }\end{array}$ & 20 anos & $\begin{array}{l}\text { Professor na rede } \\
\text { pública estadual }\end{array}$ & $\begin{array}{l}\text { Ativ. } 1.1 ; 2.1 \\
3.1 \text { e } 4.2\end{array}$ \\
\hline $\begin{array}{l}\text { Coordenador } \\
\text { Pedagógico } 1\end{array}$ & $\begin{array}{c}\text { Pedagogia e } \\
\text { Ciências Biológicas } \\
\text { - Especialista em } \\
\text { Educaçăo }\end{array}$ & 06 anos & $\begin{array}{c}\text { Professor na rede SESI } \\
\text { - EJA }\end{array}$ & Ativ. $1.2 ; 2.3$ \\
\hline $\begin{array}{l}\text { Coordenador } \\
\text { Pedagógico } 2\end{array}$ & $\begin{array}{l}\text { Pedagogia e } \\
\text { Matemática }\end{array}$ & 03 anos & $\begin{array}{c}\text { Professor na rede } \\
\text { municipal }\end{array}$ & Ativ. $2.2 ; 4.1$ \\
\hline
\end{tabular}

\section{Profissionais externos}

\begin{tabular}{|c|c|c|}
\hline Tipo de profissional & $\begin{array}{c}\text { Competências } \\
\text { necessárias }\end{array}$ & Participação no projeto \\
\hline Psicólogo & Recursos Humanos & Palestra Mobilização \\
\hline $\begin{array}{c}\text { Administrador de } \\
\text { Empresas }\end{array}$ & Comunicação & Palestra \\
\hline Pedagogo & Gestão Educacional & $\begin{array}{c}\text { Palestra e mediação da } \\
\text { atividade prática }\end{array}$ \\
\hline Psicólogo & Gestão de Pessoas & Palestra e interatividade \\
\hline $\begin{array}{c}\text { Administrador de } \\
\text { Empresas }\end{array}$ & $\begin{array}{c}\text { Planejamento estratégico } \\
\text { Pedagogo }\end{array}$ & $\begin{array}{c}\text { Palestra e mediação da } \\
\text { atividade prática }\end{array}$ \\
\hline & $\begin{array}{c}\text { Planejamento } \\
\text { Educacional }\end{array}$ & Palestra e interatividade \\
\hline
\end{tabular}

\section{Plano Financeiro} Investimentos (despesas de capital)

\begin{tabular}{|c|c|}
\hline Obras e infraestrutura & Ano 1 \\
\hline $\begin{array}{c}\text { Troca de janelas da sala } \\
\text { de reuniōes }\end{array}$ & $3.000,00$ \\
\hline & $\mathbf{3 . 0 0 0 , 0 0}$ \\
\hline Total & \\
\hline
\end{tabular}




\section{Despesas correntes}

\begin{tabular}{|c|c|}
\hline Material de consumo & Ano 1 \\
\hline Material de escritório & 350,00 \\
\hline Cartuchos de tinta & 300,00 \\
\hline Total & 650,00 \\
\hline
\end{tabular}

\begin{tabular}{|c|c|}
\hline Gastos com locomoçăo & Ano 1 \\
\hline $\begin{array}{c}\text { Locação ônibus } p / \\
\text { orquestra }\end{array}$ & $8.000,00$ \\
\hline Viagem de carro & 240,00 \\
\hline Taxi & 450,00 \\
\hline Passagem aérea & $3.400,00$ \\
\hline & $\mathbf{1 2 . 0 9 0 . 0 0}$ \\
\hline
\end{tabular}

\begin{tabular}{|c|c|}
\hline Servicos de terceiros & Ano 1 \\
\hline Palestrantes & $11.600,00$ \\
\hline Buffet coffe & $3.000,00$ \\
\hline Buffet coquetel & $5.500,00$ \\
\hline Orquestra & $6.000,00$ \\
\hline & \\
\hline Total & $\mathbf{2 6 . 1 0 0 , 0 0}$ \\
\hline
\end{tabular}

Recursos totais

\begin{tabular}{|c|c|c|}
\hline Tipo de item & \multicolumn{1}{|c|}{ Ano 1 } & Total \\
\hline Despesas de Capital & $25.500,00$ & $\mathbf{2 5 . 5 0 0 , 0 0}$ \\
\hline Obras e infraestrutura & $3.000,00$ & \\
\hline Material permanente & $22.500,00$ & \\
\hline Despesas Correntes & $38.840,00$ & $38.840,00$ \\
\hline Material de consumo & 650,00 & \\
\hline Gastos com locomoção & $12.090,00$ & \\
\hline Serviços de terceiros & $26.100,00$ & \\
\hline Total de recursos do edital & $64.340,00$ & $64.340,00$ \\
\hline Gastos adicionais & 0,00 & $\mathbf{0 , 0 0}$ \\
\hline Recursos totais & $\mathbf{6 4 . 3 4 0 , 0 0}$ & $\mathbf{6 4 . 3 4 0 , 0 0}$ \\
\hline
\end{tabular}




\section{Contrapartida}

\begin{tabular}{|c|c|c|c|}
\hline Profissionais & $\begin{array}{c}\text { Horas } \\
\text { dedicadas ao } \\
\text { projeto }\end{array}$ & $\begin{array}{c}\text { Valor } \\
\text { médio/hora }\end{array}$ & $\begin{array}{c}\text { Contrapartida } \\
\text { por profissional }\end{array}$ \\
\hline Diretor da Escola & 40 & 70,00 & $2.800,00$ \\
\hline Coordenadores & 80 & 60,00 & $4.800,00$ \\
\hline Inspetores & 48 & 10,00 & 480,00 \\
\hline Bibliotecário & 24 & 35,00 & 840.00 \\
\hline Equipe de apoio & 96 & 15,00 & $1.440,00$ \\
\hline Professores & 640 & 40,00 & $25.600,00$ \\
\hline Total de contrapartida & 928 & - & $35.960,00$ \\
\hline
\end{tabular}

